This document is the accepted manuscript version of the following article:

Trang, P. T. K., Lan, V. T. M., Viet, P. H., Berg, M., Postma, D., \& Larsen, F. (2012). Human exposure to arsenic and manganese in groundwater in the Red River De1ta, Vietnam. In J. C. Ng, B. N. Noller, R. Naidu, J. Bundschuh, \& P.

Bhattacharya (Eds.), Arsenic in the environment. Proceedings. Understanding the geological and medical interface of arsenic. As 2012 (pp. 115-117). Retrieved from https: //www. taylorfrancis.com/books/e/9780203078808/chapters/10.1201\% 2Fb12522-51

\title{
Human exposure to arsenic and manganese in groundwater in the Red River Delta, Vietnam
}

\section{P.T.K. Trang, V.T.M. Lan \& P.H. Viet}

Center for Environmental Technology and Sustainable Development (CETASD),

Hanoi University of Science, Vietnam

\section{Berg}

Swiss Federal Institute of Aquatic Science and Technology (Eawag), Switzerland

D. Postma \& F. Larsen

Geological Survey of Denmark and Greenland, Copenhagen, Denmark

\begin{abstract}
Household tubewell water extracted from Holocene aquifer is remaining a major drinking source for the farmer in the Red river delta in the North Vietnam. Higher levels according to WHO safety guideline $(10\lceil\mathrm{~g} / \mathrm{L}$ for Arsenic (As) and $0.4 \mathrm{mg} / \mathrm{L}$ for Manganese $(\mathrm{Mn})$ were found either for arsenic or manganese in $58 \%$ of 512 wells. The average arsenic levels in groundwater are 229, 425 and $261 \int \mathrm{g} / \mathrm{L}$ $(P<0.05)$ in three hot sports namely Dan Phuong, Ly Nhan and Hoai Duc respectively. The arsenic concentrations in the treated groundwater using sand filter tanks were reduced remarkably; they are 29, 35 and $144 \int \mathrm{g} / \mathrm{L}(P<0.05)$ respectively. At control site, Tu Liem, the average hair arsenic concentration is $0.3 \mathrm{mg} / \mathrm{kg}$. At contaminated sites, Dan Phuong, Ly Nhan and Hoai Duc, the levels of arsenic in hair are $0.6 ; 0.8$ and $1.4 \mathrm{mg} / \mathrm{kg}(P<0.05)$ respectively.
\end{abstract}

\section{INTRODUCTION}

The Red river delta locates in lower section of the Red river that goes through the north Vietnam. It has the area of $15.000 \mathrm{~km} 2$. The surface sediment is alluvial soil with the thickness of $80-100 \mathrm{~m}$. The alluvial layer is thinner in the edge area. The population of the delta is about 19 millions, $80 \%$ of them live in the countryside. The groundwater abstracted via tubewells is one of the major drinking sources for the inhabitants especially in the dry season.

\section{METHOD}

\subsection{Sample collection}

512 water samples from family tubewells were colleted. The sampling density is $25 \mathrm{~km}^{2} /$ sample in the area of $10000 \mathrm{~km}^{2}$. The tubewells are deep from 4 to $135 \mathrm{~m}$, with average of $34.7 \mathrm{~m}$. Arsenic, manganese and other 20 chemistry elements were analyzed [Winkel 2011]. For arsenic accumulation evaluation, three contaminated villages and one control village were selected. 63 water samples, 183 hair samples were taken in the contaminated villages and 5 water samples and 30 hair samples from control village.

\subsection{Chemical analysis}

The filtered, acidified water samples $(\mathrm{pH}<2)$ and microwave digested hair fluids that contain dissolved inorganic arsenic in acidic environment were analyzed. The arsenic in the solutions was determined by HVG-AAS. Manganese in the water was analyzed by flame AAS (AA6800Shimadzu).

\section{RESULTS AND DISCUSSION}

\subsection{Arsenic and manganese contamination in the tubewell water}

The analyzed data from 512 water samples showed that arsenic concentrations in these water samples are in the range of $<1397 \mathrm{~g} / \mathrm{L}$, with the average

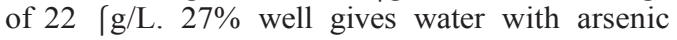
concentration higher than WHO safety drinking guideline $(10\lceil\mathrm{~g} / \mathrm{L})$. Also in above 512 wells, manganese contents are from $<0.05$ to $17 \mathrm{mg} / \mathrm{L}$, with the average of $0.8 \mathrm{mg} / \mathrm{L}, 41 \%$ well provided water with manganese higher than $0.4 \mathrm{mg} / \mathrm{L}$, it is WHO safety guideline for manganese. $58 \%$ wells are contaminated either arsenic or manganese. Arsenic and manganese levels in these samples are 
often in irreversible. There are many samples that contain high arsenic and low manganese and vice versa. The arsenic contamination is prominent in $20 \mathrm{~km}$ wide band along the NW-SE boundary of the delta plain [Winkel 2011].

\subsection{The arsenic contamination in tube well water in some hot spots}

Three arsenic hot spot villages were selected for more dense sampling. They named Dan Phuong, Ly Nhan, and Hoai Duc. The average arsenic concentration at Dan Phuong was 229 g/L $(\mathrm{n}=13)$, in the range of $<1-632(\mathrm{~g} / \mathrm{L}$. At Ly Nhan, the average arsenic concentration was 425 (g/L $(\mathrm{n}=15)$, range $311-598(\mathrm{~g} / \mathrm{L}$. At Hoai Duc, the average arsenic concentration was $261\lceil\mathrm{~g} / \mathrm{L}(\mathrm{n}=35)$, range $<1-377(\mathrm{~g} / \mathrm{L}$. The arsenic contaminations were either homogenous as in Ly Nhan, Hoai Duc or heterogeneous as in Dan Phuong. The arsenic contamination in these places is comparable with reported areas in the Middle Ganga Plain and the West Bengal, India, where arsenicosis patients are found (Rahman 2005). But only few patients in the Red River Delta have been diagnosed so far. In Northern Vietnamese villages, the people often collect and drink rain water during the summer time. It probability attributes to the non continuous arsenic exposure of the human. Beside of that, groundwater has been filtered through the sand filter tanks. That made arsenic in treated water reduced dramatically.

\subsection{The removal of arsenic by sand filter}

The average arsenic concentrations in the sand filtered water samples collected in Dan Phuong, Ly Nhan and Hoai Duc were 29, 35 and 144 /g/L. They are decreased remarkably compared to the original levels in groundwater 229, 425 and $261 \mathrm{~g} / \mathrm{L}$ respectively. The average arsenic removal efficiencies of the sand filters were 85 and $91 \%$ in Dan Phuong and Ly Nhan. These were comparable with the results reported before (Berg 2006). However, the arsenic levels were still high in Hoai Duc, with only $44 \%$ of arsenic trapped by the sand filters. The arsenic removal efficiencies of the sand filters are affected by iron concentrations in water, more iron higher arsenic removal efficiency. Our results showed that the average iron contents in Dan Phuong, Ly Nhan were rather high (12.1 and $15 \mathrm{mg} / \mathrm{L})$, but low in Hoai Duc (6.3 mg/L). Assuming that the people always use the treated water by sand filters and their arsenic filter yields are stable all the times then the actual arsenic exposures of the people at the studied villages are reduced significantly.

\subsection{Arsenic levels in human hair}

We analyzed total arsenic in the 213 hair samples from the residents living in four villages. At the control site $(\mathrm{Tu}$ Liem), where arsenic levels in water are $<1(\mathrm{~g} / \mathrm{L}$, the average arsenic concentration in hair was $0.30 \mathrm{mg} / \mathrm{kg}(\mathrm{n}=30)$, range $0.1-$ $0.8 \mathrm{mg} / \mathrm{kg}$. The average arsenic level in human hair in Dan Phuong was $0.6 \mathrm{mg} / \mathrm{kg}(\mathrm{n}=40)$, range $0.1-2.3 \mathrm{mg} / \mathrm{kg}$, in Ly Nhan was $0.8 \mathrm{mg} / \mathrm{kg}$ $(\mathrm{n}=51)$, range $0.2-4.0 \mathrm{mg} / \mathrm{kg}$, and in Hoai Duc was $1.4 \mathrm{mg} / \mathrm{kg}(\mathrm{n}=92)$, range $0.2-7.5 \mathrm{mg} / \mathrm{kg}$.

Combining all the hair data from the four villages and evaluating by the cut off value of the arsenic level of $50 \mathrm{~g} / \mathrm{L}$ in the sand filtered water, the percentages of the hair samples against to the arsenic content ranges are plotted. The distribution reveals that, while more than $90 \%$ populations ( $\mathrm{n}=115$ ) exposed to the levels $<50 \quad \mathrm{~g} / \mathrm{L}$ had arsenic in their hair lower than $1 \mathrm{mg} / \mathrm{kg}, 64 \%$ of the residents $(n=98)$ exposed to the levels $>50(\mathrm{~g} / \mathrm{L}$ had arsenic in their hair higher than $1 \mathrm{mg} / \mathrm{kg}$, the level that might be related to skin pathology (Chakraborti 2003). It means that the later populations were risk for arsenic intoxication and probably the arsenicosis disease will manifest in the near future.

\section{CONCLUSION}

The arsenic or manganese contamination in 58\% tubewell water samples in the Red river delta were reported. In the heavy arsenic contaminated villages (As > $50(\mathrm{~g} / \mathrm{L}$ ), about $64 \%$ hair samples contained arsenic at the levels higher than $1 \mathrm{mg} / \mathrm{kg}$, the level related to the arsenic intoxication diseases. It might be harmful for health of the residents living in the Red River Delta if the exposure will be continuous without any mitigation measures. The filtration of arsenic from groundwater using the sand filter showed the positive impact reducing arsenic exposure and accumulation in the human body.

\section{ACKNOWLEDGEMENT}

The study was funded by SDC, NAFOSTED and DANIDA, we highly appreciate the supports.

\section{REFERENCES}

Berg M., Luzi S., Pham. T.K.T., Pham H.V., Giger W. Stuben D. 2006. Arsenic removal from groundwater by household sand filters: Comparative field study, modal calculation, and health benefits. Environment Science and Technology 40:5567-5573. 
Chakraborti D, Mukherjee S.C., Pati S.,
Sengupta M.K., Rahman M.M., Chowdhury U.K., Lodh D., Chanda C.R., Chakraborti A.K., Basu G.K. 2003. Arsenic groundwater contamination in middle Ganga plain, Bihar, India: A future danger? Environmental Health Perspectives 111 (9): 1194-1201.

Rahman M.M., Sengupta M.K., Ahamed S. Chowdhury U.K., Hossain M.A., Das B., Lodh D., Saha K.C., Pati S., Kaies I., Barua A.K., Chakraborti D. 2005. The magnitude of arsenic contamination in groundwater and its health effects to the inhabitants of the Jalangi- one of the 85 arsenic affected blocks in West Bengal, India. Science of the Total Environment 338: 189-200.
Winkel L.H.E., Pham T.K.T, Vi M. L, Stengel C., Amini M., Nguyen T.H, Pham H.V, and Berg M. 2011. Arsenic pollution of groundwater in Vietnam exacerbated by deep aquifer exploitation for more than a century. Proceeding of National Academy of Science (PNAS), 108 (4): 1246-1251. 